КОНЦЕПТ "ЕВРОПА" В СОВРЕМЕННОМ ПОЛИТИЧЕСКОМ ДИСКУРСЕ

\title{
К.Е. Петров
}

\section{ВВЕДЕНИЕ}

Устойчивость любой складывающейся общности поддерживается не только институциональной структурой, но и способом именования новой реальности. Это в полной мере относится и к такой организации, как Европейский Союз (ЕС). Даже самый поверхностный анализ показывает, что на уровне политических институтов интеграционные достижения европейских государств не очень значительны и ЕС представляет собой непрочное единство [Brubaker 1996: 16; Обердорфф 2001: 7]. Однако идеологическую экспансию понятия единой Европы трудно подвергнуть сомнению. Недавнее расширение "Европы-15" до "Европы-25" свидетельствует об успехе "общеевропейской идеи" как центрального концепта, создающего идентичность и структурирующего социальное пространство.

При создании новой политической общности неизбежно возникает потребность в конвенциализации дискурса, который будет обеспечивать ее единство. Сопутствующие изменения в структуре дискурса могут трактоваться и в качестве субъективных, направляемых волей субъекта объединения, и в качестве объективных, проявляющихся стихийно. Как бы то ни было, конвенциализация дискурса происходит идеологично, т.е. по мере своего развития исключает некоторые смыслы. Действия политических акторов есть лишь актуализации идеологизированных аргументаций*.

Никакая политика не в состоянии обойтись без использования конвенциональных значений присутствующих в дискурсе концептов. Сегодня уже можно говорить о легитимной субъективизации концепта "Европа" и его самостоятельной жизни в рамках дискурса**. Вместе с тем любые представления о природности европейского единства суть идеологические выражения политической борьбы***.

Идея единой Европы зародилась в интеллектуальной среде, проникла в политику и, наконец, стала массовой, оформившись в виде центрирующей дискурс метафорической структуры. Настоящая статья посвящена анализу характера и функций этой метафорической структуры. Одновременно в ней будет рассмотрена производная от концепта "Европа” категория “европейская идентичность”. Подобно идее единой Европы, данная категория явилась продуктом особого рода интеллектуальной культуры и лишь постепенно превратилась в неотъемлемую часть политической реальности.

Предлагаемая работа призвана объяснить, каким образом денотативно географический “термин”, обросший многовековыми слоями разнообразных значений, может создавать и легитимировать современные политики. В ходе исследования автор опирался на конструктивистскую парадигму понимания социального знания, методы дискурс-анализа и методологические наработки ряда современных философов.

ПЕТРОВ Кирилл Евгеньевич, студент РГГУ.

* О развитии подобных актуализаций и его пределах см. напр. Шпенглер 1993; Коукер 2000. Интересно заметить, что сам шпенглеровский тезис о распаде Европы предполагает ее единство и определенность, поскольку в противном случае невозможно постулировать и анализировать процесс распада.

** Показательно, в частности, что во многих документах ЕС, не говоря уж о медиа-текстах, Европа выступает в качестве подлежащего, т.е. субъекта, направляющего те или иные процессы.

*** Вследствие неопределенности восточной границы Европы [Фуше 1999; Европейская интеграция 2001] она проводится по телеологическим основаниям. Это наглядный пример того, как география подчиняется политическому целеполаганию. 
Согласно конструктивистской парадигме, идентичности и интересы субъектов не даны им от природы, но создаются разделяемыми обществом идеями: ими, а отнюдь не фактами материального мира детерминированы структуры человеческих ассоциаций [Wendt 1999]. Конструктивизм не склонен проводить значимое различие между условным фактом и условным соображением (мнением). Будучи эксплицирована, любая идея становится фактом социальной реальности. Указанная закономерность наиболее очевидна, когда идея концептуализируется в одном слове, а это слово, появившись на свет как термин, характеризующий ту или иную частную ситуацию, начинает обозначать совокупность похожих ситуаций и нарастающая метафорика постепенно подавляет однозначность конкретного значения. Именно это и произошло с концептом “Европа". Многообразные варианты его использования едва ли можно не то что проанализировать, но хотя бы перечислить. История данного концепта - сплошная череда включений в различные политические проекты, как сугубо теоретические, так и воплощенные на практике. В связи с этим в нем невозможно однозначно выделить денотативное и позднейшие коннотативные значения.

Постоянное воспроизводство типичного в понимании ситуаций создает устойчивые фреймы (концептуальные структуры), минимизирующие когнитивные издержки субъектов и удерживающие сознание в кругу дискурсивно допустимых интерпретаций. Подобного рода конвенциализация имплицитно предполагает редукцию смыслов, которая позволяет доминирующему дискурсу отделять исторически значимое от исторически незначимого и контролировать поле интерпретаций. Как отмечает Х.Р.Олкер, “исторические ограничения и возможности” проще всего понять “в терминах таких формальных конструктов, как сценарии Шенка и Абельсона" или “'сюжетные свертки' Ленерт, Рикера и Уайта"* [Олкер 1987: 412]. По сути дела речь идет о том, что в процессе субъективной перцепции идеи, представленные в концептуальных структурах, способны трансформироваться в сложные (но формализованные) метафоры или символы, которые встраиваются в фреймовые структуры. Помимо перечисленных выше конструктов, к их числу можно отнести сценарии T.А.ван Дейка [Dijk 1982; Дейк 2000], эмоциональные сюжетные структуры [Олкер-мл. и др. 2001], а также коннотативно ориентированные псевдоприродные знаковые системы, которые исследовал Р.Барт [Барт 2000, 2001]. Иными словами, структурирование и отбор фактов - не просто неотъемлемая часть мышления, но и важный компонент процесса идеологизации дискурса или, выражаясь языком Р.Барта, мифологизации действительности.

Политика оказывается конструкцией “в квадрате”, ибо более или менее обшие политические представления вбирают в себя концепты с заведомо широким полем значений. Кроме того, концепты обладают мощным когнитивным потенциалом, благодаря которому они воздействуют на понятийную систему, выступая в качестве инструментов, а иногда - и субъектов политического влияния.

Особо важную роль в этом смысле играют “фундаментальные” термины, т.е. слова, которые позволяют субъектам политического процесса охарактеризовать и проблематизировать ситуацию, а затем обозначить альтернативы и привлечь ресурсы для достижения одной из них. Вместе с тем все эти конструкции в конечном счете упираются в первичные концептуализации, скажем, географического пространства. Взгляд на "Европу” как ядро развития - классический пример подобной концептуализации [Wallerstein 1974]. Не стоит забывать и о длительном историческом существовании концепта, в ходе которого многочисленные метафорические схемы сменяли друг друга, но ни одна из них не смогла полностью подавить другие**. С появлением ЕС данный концепт получил новое толкование, призванное с помощью сложной комбинации метафорических значений свести в

* О сценариях Р.Шенка и Р.Абельсона см. Шенк 1980; Абельсон 1987; о “сюжетных свертках” Ricoeur 1981; Lehnert 1981

** Многозначность данного концепта иногда объясняют тем, что он “отражает политическое и национальное разнообразие Европы” [Фуше 1999]. 
единую, возможно, иерархическую структуру то гетерогенное "нечто”, которое лучше всего определяется формулой: "географически близкое Западной Европе".

Идеи, высказанные в работах М.Джонсона и Дж.Лакоффа [см., напр. Lakoff, Johnson 1980; Lakoff 1987, 1992], позволяют увидеть в концепте "Европа" пространство реализации потенциальных метафор. Эти метафоры могут представлять "Европу" либо как некий объективно существующий феномен (вещь), либо как особую (читай, уникальную, не географическую!) часть мира.

Для прояснения характера отношений между смыслом и вещью целесообразно прибегнуть к методу дискурс-анализа как одному из наиболее эффективных инструментов поиска сопряженностей между языковой и социальной (а тем самым - и идеологической) сферами [Пульчинелли 2002]. В рамках дискурс-анализа мир вещей предстает формой навязывания реальности ее смысла путем идеологического обрашения к субъекту [Пеше 2002], а сам субъект - лишь “элементарным идеологическим эффектом” [Althusser 1970:30]. Именно в дискурсе находит свое материальное выражение связь между речевой деятельностью и идеологией [Ркsheux 1969].

Поскольку понятие "дискурс" не имеет конвенционального определения, сразу же оговорюсь, что при его использовании я исхожу из двух основных постулатов: (1) дискурс образуется из всей совокупности “индивидуальных актов воли и разума"* по некоторому вопросу; (2) дискурс, подобно языку, обладает структурой; он ограничен социально и лишь опосредованно (через социум) зависит от индивидуальных речевых актов**. Отсюда следует, что, рассматривая, как социальный агент “Европа" проявляет себя в коммуникативных формах, мы одновременно изучаем дискурс. Выделение дискурсов, подлежащих анализу, зависит от целей исследования. В настоящей работе были проанализированы четыре пересекающихся, но все же относительно автономных дискурса: (1) дискурс официальных документов и деклараций Евросоюза, (2) дискурс политических лидеров стран - членов ЕС, (3) дискурс СМИ и, наконец, (4) дискурс научной литературы.

Возврашаясь к метафоре “Европа - вещь”, необходимо отметить, что любая вещь существует лишь в связи с человеком и сотнями других вещей спутников человеческого. Если нас интересует овеществленная метафорой Европа, то ее материальность можно ощутить только в ходе изучения дискурса. Но как совместить утверждение о “вещественности” Европы в человеческом сознании с утверждением о возможности существования образования "вещьЕвропа" лишь в рамках некоего дискурса? Путь к решению этой проблемы, на мой взгляд, открывает мысль Ж.Бодрийяра о тождественности изучения вещей изучению "процессов человеческих взаимоотношений” [Бодрийяр 1995: 4]. Методологически данное положение опирается на тот факт, что при исследовании системы "вербализованных" вещей (другими словами, связной системы значений, или дискурса) мы всегда сталкиваемся с иным "невербальным" уровнем - мощно структурированным уровнем технологии. Правда, выдвигая этот тезис, французский философ имел в виду главным образом бытовые вещи, сферу их технологичности и функциональности, а исследуемую “вещь” трудно отнести к бытовым. Но при рассмотрении системы вещей как скрытой идеологии, ее симулякра, принадлежность “Европы” к современной системе вещей становится вполне очевидной. Здесь можно привести слова Ю.Хабермаса: “Взамен больших идеологий прошлого, прямо и открыто формулирующих интересы классов, сегодня общество объединяется системой вещей, комфортом, рынком, рациональностью” [Хабермас 2000: 275].

Изложенные выше соображения позволяют более четко определить задачу данного исследования. Она заключается в создании внутренне когерентной объ-

* То есть речи, в трактовке Ф. де Соссюра [Соссюр 1977: 52].

** Противопоставление речи и языка носит здесь не риторический, а методологический характер. Как пишет П.Ф.Стросон, “не следует ожидать, что человек, в совершенстве овладевший языком, сможет теоретически сформулировать суть того, что он применяет на практике” [Стросон 1986: 160-161]. 
яснительной модели функционирования концепта "Европа" (и поддерживающих дискурсов) в политике Европейского Союза. По сути дела речь идет о попытке применения методик реконструирования схем мышления и анализа дискурсивных нарративов к конкретному концепту, значения которого неразрывно связаны с политической историей, а также с развитием политической философии и систем генерализации знаний вообще [Axelrod 1976; Bonham et al. 1997].

\section{ИДЕЯ ЕВРОПЕЙСКОГО ЕДИНСТВА: ИСТОРИЧЕСКИЙ АСПЕКТ}

Прежде чем приступать к анализу современного состояния концепта "Европа” и скрывающихся за ним метафорических систем (система вещей и система знаков международной политики, отражающая деление мира на части), представляется целесообразным сделать небольшой экскурс в историю и посмотреть на генезис идеи европейского единства.

Мечта об объединенной Европе возникла очень давно. Ее отзвуки можно найти в трудах многих мыслителей прошлого. Европейские интеллектуалы и философы любили рассуждать о европейском единстве - культурном, религиозном. Нередко высказывалась мысль и о возможности единства политического, разрабатывались конкретные проекты его достижения. К их числу относится, в частности, проект В.Пенна (1693 г.), предусматривавший создание сейма, “который объединил бы представителей европейских государств с целью прекращения войн, их раздираюших" [Обердорфф 2001: 13]. В "Проекте вечного мира" аббата де Сен-Пьера (1712 г.) доказывалась необходимость создания "Европейского Сената", наделенного законодательными и судебными полномочиями, решения которого были бы обязательны для государств. Идеи де Сен-Пьера широко обсуждались в интеллектуальных кругах, но вызывали неоднозначную реакцию. Так, например, Ж.Ж.Руссо отнесся к ним довольно скептически, назвав надежды на прекращение войн в Европе “тщетными" [Руссо 1969: 150].

У идеи политического объединения Европы были и противники. Весьма показательна в этом отношении концепция "острова на европейском континенте” И.Г.Фихте. Согласно этой концепции, чтобы достичь могущества, государства должны полностью замкнуться, в т.ч. и в хозяйственном плане. Для граждан идеального государства, утверждал Фихте, недопустимы никакие экономические отношения с заграницей. Симптоматично, однако, что, выступая за автаркию, он делал исключение для науки и искусства: они носят всеобщий характер, а потому не могут развиваться в изоляции [Фихте 1995: 39-42]. Подлинное значение этой оговорки можно понять, если обратиться к философии Д.Вико [Вико 1994]. Подразделяя историю человечества на три великие эпохи: богов, героев и людей, Вико писал, что христианская Европа, пройдя все этапы созревания, может и должна сберечь зерна цивилизации в чистоте и неприкосновенности [см. Реале, Антисери 1997]. Смысл данного тезиса, по сути, сводился к тому, что в европейской истории присутствует некое дорефлексивное связующее звено или, если угодно, интегративная база.

Приведенный пример свидетельствует о том, что идея европейского единства могла выражаться не только в проектах, нацеленных на создание надгосударственных властных институтов. Наряду с такими "формальными" проектами существовали и "ценностные" ("неформальные"), основанные на (пред)понимании единства Европы как внеинституциональной реальности.

Первый строго "неформальный" проект - "К вечному миру" - принадлежал перу И.Канта, который искал опору для объединения Европы не в легальных институтах, а в свободной воле и этических принципах объединяющихся государств [Кант 1994]. Этот проект, как мне кажется, и стал предтечей современной идеологии объединения. Представление о связи между интеграцией и всеобщим стремлением к миру лейтмотивом проходит через документы Евросоюза. "Только мир и совместные действия смогут сделать мечту о сильной, единой Европе реальностью", - говорится, например, в Лакенской декларации 2001 г. [Laeken Declaration 2001]. Та же мысль постоянно проводится и на сайте EC, созданном специально для интернет-пользователей США [см. www.eurunion.org]. 
В известном смысле образование Евросоюза явилось результатом синтеза “формального" и “ценностного" походов к объединению Европы. Институционально современная политическая линия ЕС базируется на “формальных" проектах, однако свою интегрирующую силу она, вне сомнения, черпает из ценностных. Как подчеркивал в знаменитой Декларации 1950 г.* один из основателей ЕС Р.Шуман, "чтобы мир мог быть обеспечен, необходимо, чтобы существовала Европа" [Шуман 2002: 90]. Но наиболее отчетливо синтез двух интеллектуальных направлений выражен в следующем тезисе Шумана: "Путем... создания Высшего Органа власти... будут заложены первые конкретные основания европейской Федерации, необходимой для сохранения мира" [Шуман 2002: 92].

Впрочем, вопрос о “формальной" стороне объединения до сих пор остается открытым. Хотя общеевропейская конституция - уже почти реальность**, спор об институциональном дизайне ЕС и масштабах делегирования суверенитета далеко не закончен***. Руководство Евросоюза пока не готово предложить план дальнейшей интеграции, стратегическая (и ценностная) цель которой предельно ясна. Вероятно, желание эксплицировать такую цель сдерживается страхом перед новой волной национализма. На настоящий момент не ясно, когда же мы сможем констатировать, что Европа стала единой. Даже языковые дефиниции (вроде языковых ловушек, связанных с проблемой географических пределов Европы) способствуют пониманию единой Европы в качестве процесса, а не факта. Европа "родилась, но еще не пришла к своему единству. Это - процесс в начальной стадии, результат многочисленных наследий, разных исторических пластов... Ядро европейской культуры, менталитета и обычаев восходит к Средневековью. На эту основу потом наслоились Возрождение, Просвещение, Романтизм, Позитивизм и т.д.", - так в интервью газете "Corriere Della Sera" комментирует происходяшее историк школы “Анналов” Ж. ле Гофф [http://www.inosmi.ru/translation/142335.html]. Приведенный фрагмент отчетливо демонстрирует неоднозначность концепта "Европа", который каждый раз как бы “расщепля-

144 ется" в сознании людей. Такое “расщепление” обусловлено, в частности, тем, что Европа существует не только в настоящем; как смысловое поле она серьезным образом коррелирует с ценностным отношением к собственной истории.

Как видно из сказанного выше, ключевой ценностью, заложенной в концепте "Европа", всегда было поддержание мира. Панъевропейские пацифистские взгляды высказывались философами, государственными деятелями и поэтами. К началу XXI в. к этой ценности добавилась еще одна. В рассуждениях современных политиков идея Европы переплетена с идеей не только мира, но и демократии. Дополняя друг друга, эти идеи обеспечивают ценностную и эмоциональную аргументацию в поддержку интеграционных процессов. При этом показательно, что метафору перехода в качественно новое состояние сегодня все больше заменяет метафора возвращения к утраченному единству****.

\section{МЕТАФОРИЧЕСКИЕ СИСТЕМЫ}

Обратимся теперь к метафорическим моделям представления действительности, стоящим за концептом “Европа”. Такие модели, как уже упоминалось, строятся либо на отделении/спецификации ("Европа есть уникальная часть мира”), или на овеществлении (“Европа есть вещь”). Каждая из двух основных метафор, в свою очередь, может быть развернута в две метафорические системы: (1) "Европа - комфорт обжитого мира" и "Европа - технологичность современного мира”; (2) “Европа - ценность старинной вещи” и “Европа - уникальность функциональной вещи”. Именно эти четыре метафори-

* О процессе подготовки текста декларации см. [Монне 2001: 364-368].

** Ее подписание, планировавшееся на май 2004 г., было затем перенесено на месяц.

*** В декабре 2003 г. Польша и Испания заблокировали выдвинутый на обсуждение проект конституции [European Summit 2003].

**** См. например аргументацию Т.Блэра в день расширения ЕС (01.05.2004) [The Prime Minister's 2004]. 
ческие системы позволяют вербально “переводить” Европу в материальные факты. Постоянно подменяя одна другую в ходе выстраивания политической аргументации, они, по-видимому, и создают ту самую идеологию ЕС, которая образует стержень современных интеграционных процессов.

Обозначенные выше две пары метафорических систем не только противостоят друг другу, но и внутренне антагонистичны. Данный антагонизм описывается отношением: "Риск современного" versus "Вечность исторического".

\begin{tabular}{|l|l|}
\hline Метафора, центрирующая систему & Оппозиция \\
\hline Европа - комфорт обжитого мира & Риск \\
\hline Европа - технологичность современного мира & Старина \\
\hline Европа - ценность старинной вещи & Риск \\
\hline Европа - уникальность функциональной вещи & Старина \\
\hline
\end{tabular}

Следует отметить, что дискурс, как правило, оказывается не в состоянии отразить это противостояние, столь явственно ощутимое при выделении метафор. В его рамках, например, прекрасно могут сосуществовать такие фразы: "Сегодня мы твердо уверены: все 10 стран являются демократическими нациями, придерживающимися тех же самых ценностей, что и остальная Европа” [PM Statement 2002] и "Европа становится Европой 25-ти. Это огромное изменение для Европы" [Doorstep interview 2003]. Обнаружить реальное противоречие между этими высказываниями премьер-министра Великобритании Т.Блэра можно только через отрефлексировав метафорику. В одном из них подчеркивается ценностное единство Европы как части мира, в другом фиксируется уникальность Европы и ее способность к изменению (“вещность”). Очевидно, что в первом случае ЦВЕ входит в состав “Европы”, а во втором нет. Более того, указанные метафорические системы несут в себе противоположный смысл: образ освоенного и окультуренного мира, обеспечивающего полноценность жизни, трудно экстраполировать на страны ЦВЕ, но они легко могут обрести функциональную значимость посредством участия в институтах ЕС. Подобная ситуация позволяет политикам легитимировать любое свое решение путем комбинирования метафор.

Посмотрим, как действуют метафорические системы при конструировании категорий мышления.

“Европа - комфорт обжитого мира" / "Европа - технологичность современного мира”. Представляя Европу в качестве уникальной по комфорту и уровню жизни части планеты, мы отбрасываем все географические дефиниции. "Зачисление" в Европу происходит на основании объема ВВП на душу населения и прочих экономических показателей. Комфортность существования надежно отгораживает Европу от остального (опасного) мира, придает ей ценность эталона и при этом дискурсивно противопоставляет рискованному динамизму других экономических и политических систем, в первую очередь - США.

Использование данной метафоры хорошо объясняет (с оттенком упрека) мощную волну протестов в европейских странах против военной операции в Ираке и одновременно позволяет легитимировать внешнюю политику США как единственной державы, оказавшейся способной взять на себя ответственность за этот шаг, несмотря на сопутствующий риск. Таким образом, беспрецедентность положения Европы как зоны внутреннего мира и процветания [см., напр. Gordon 2003; Butler 2003] превращается в негативную характеристику, которая мешает пониманию самоочевидной для многих исследователей истины: ценности и устремления американцев и европейцев идентичны [см., напр. Фукуяма 1999], между их установками относительно власти, военной силы и суверенитета нет фундаментальных различий.

Связь между метафорами “Европа - комфорт обжитого мира” и “Европа технологичность современного мира” легко проследить на примере дискурса меж- 
дународных отношений. Рассмотрим такие геополитические термины, как Европа, Америка, Ближний Восток, Юго-Восточная Азия, или их означающие: “Старый Свет”, “Новый Свет”, “Нефтяной регион”, “Азиатские тигры”. Вместе они образуют некое целое, привычно оформляя международные отношения. При этом большинство геополитических номинаций представляют собой главные "вещи" в международной политике, выступающие в роли опознавательных знаков. Именно в "знаковости” и состоит их функциональная нагрузка.

В рамках системы международных отношений “вещи” (или их обладатели) стремятся к реализации двух противоположных целей: стать максимально распространенными (т.е. разделить типичность современных технологий) и максимально уникальными (другими словами, не допустить типизации). Только эти "противостояния" позволяют "вещам" добиться абсолютной “знаковости”, заменив собой и владельца, и любые связанные с ним “вещи”. Но достижению первой из указанных целей препятствует конкуренция идентичностей, а осуществлению второй - угроза изоляции. Кроме того, продвижение в одном направлении означает отступление в другом. Например, принятие Турции в ЕС, обеспечивая Европе сопричастность Малой Азии, одновременно “уничтожает” ее уникальность. Битва между точностью значений и экспансией смысла продолжается, а потому остается изменчивой и вещественность опознавательных знаков.

Стремление концептов стать “знаком” всего и вся - отличительная черта дискурса международных отношений. Абсолютная “знаковость" покрывает собой все его составляющие, а значит - способна включать в себя подавляющее большинство субъектов и трансформировать их идентичности. Однако “знаковость" амбивалентна: так, Америка предстает то уникальной страной бесконечных возможностей (читай: страной, которую невозможно повторить), то образцом для подражания, навязывающим другим свои модели общественного устройства. То же самое касается и Европы: чтобы до конца разобраться в ее знаковой системе, потребовалось бы создать каталог сравниваемых с ней "вещей” или частей мира. Вместе с тем очевидно, что Европе пока не удалось закрепиться в качестве доминирующего “знака" международной системы. Единственным “знаком”, без выражения отношения к которому сегодня нельзя обойтись, является Америка.

“Европа - ценность старинной вещи” / "Европа - уникальность функииональной вещи”. Зачастую Европе приписываются свойства “старинной вещи” в том значении, которое ей придавал Ж.Бодрийяр. Постулируя "особость и знаковость” такой вещи, философ писал: “Поскольку ее задача в рамках 'среды' - заколдовывать время и переживаться как знак, то она не отличается от любого другого элемента и соотносится с ними всеми. Поскольку же, напротив, она обладает меньшей соотнесенностью с другими вещами и выступает как нечто целое, как некая наличная подлинность, то у нее появляется спещиальный психологический статус” [Бодрийяр 1995: 62]. Указанный статус уже есть своего рода политика, ибо он придает устойчивость всей системе привычных вещей, цепляясь за каждую ее частичку. Манипулируя "старинной вещью", высвечивая нужные грани, можно эффективно структурировать социальное пространство. "Старинная вещь" является “куском" абсолютной реальности. Она потенциально способна собирать рассеянное в вещах бытие, придавать ему самотождественность изначального состояния мира. Поэтому “старинный предмет" - это не аксессуар и даже не просто один из культурных знаков среди прочих: в нем заключены внутренняя трансцендентность и средоточие реальности. Вслед за Бодрийяром можно отметить, что подобные иллюзии “историчности" - основа мифологического сознания, более того, ими живет всякое индивидуальное сознание. Проецируемая деталь оказывается эквивалентом "Я", вокруг которого организуется весь остальной мир. Именно по этой схеме и идет построение идентичности вокруг единственно ценной вещи - “старой доброй Европы”.

Концепт “Европа" всегда существовал лишь как часть культурной среды. Тем не менее было бы неверным называть его вторичным, поскольку неконтролируемый личностью культурный фон влияет на все остальные системы, наде- 
ляя их определительными ярлыками, структурируя постоянно растущую массу вещей. Но абсолютная культурная абстрактность сменяется жесткой формой новых конкретных институтов: Европейский Союз стремится утвердить себя в мире с помощью Европы. По сути дела эта организация претендует на все в "Европе", всячески пытаясь подменить ее. Новая Европа Евросоюза четко вписывается в систему привычных вещей с привычными функциями государствамашины, охватывающими все больше сфер деятельности человека. Но сама она еще не стала такой привычной вещью, подобно тому, как США, постоянно присваивая себе именование “Америка", не могут до конца отождествить ее с собой. Фактически Америка находится в той же системе вещей, что и Европа, отражая в себе (и узурпируя) все вещи, которые так или иначе связаны с ней. Она видится воплощением всего самого нового и функционального, однако с привычной оговоркой-оглядкой на почетного предка - Европу.

Евросоюз прилагает немало усилий, чтобы разрушить такой образ европейского, представляя единую Европу в качестве первопроходца, указывающего другим странам и народам пути развития [см., напр. Laeken Declaration 2001]. Но сломать систему, в которой Европа - это старая вещь, которая существует для того, чтобы в сравнении с ней был ощутим прогресс, чтобы новая технологичная цивилизация чувствовала свою “природность”, пока не удается. И хотя новый пласт легитимации, устремленный в будущее, отчетливо вырисовывается, на настоящий момент Европа сильна прежде всего “историчностью”. Поэтому основная задача ЕС заключается в том, чтобы привести нарратив этой истории "в порядок", - ведь если вместо идеологии строительства нации-государства в нем утвердится движение к европейскому единству, проблему построения "общеевропейской” идентичности можно считать решенной.

Попытка альтернативного прочтения метафоры “овеществления" ведет к появлению следующей, довольно искусственной, конструкции: "Европа уникальность функциональной вещи".

1 января 2002 г. произошло событие, которое еще не оценено должным образом. Введение единой европейской валюты* способно стать мощной основой для формирования “европейской” идентичности. "Евро” является “первой вещью" Европы Евросоюза: уже одним своим существованием оно как бы отвечает на вопрос о единстве Европы, единстве функциональном, которое в прямом смысле можно подержать в руках.

Новая валюта позволяет каждому “причаститься" к единой Европе, переживать ее "непосредственно". Но, будучи сильным ходом, введение "евро" одновременно выражает и слабость ЕС. Отказ от этой валюты Дании, Швеции и Великобритании серьезно подрывает доверие к ней. Сами банкноты кажутся скучными: мосты и окна, навязчиво подчеркивающие открытость, чересчур абстрактны и “рационально символичны”. Наиболее интересная деталь - изображенная на купюрах “туманная" карта Европа, которая однозначно указывает на цели не только "евро", но и Евросоюза: сделать Европу “безграничной”. Но даже здесь отсутствует драматизм в подаче нового. Более того, такая расплывчатая карта отчетливо демонстрирует крайнюю неопределенность того, что есть "Европа".

И все же единая валюта, повторю, сильный ход, невзирая на обилие скептических мнений по поводу ее экономической эффективности. При всех своих недостатках она будет планомерно расширять легитимность Евросоюза, ибо отказаться от нее теперь - слишком большая роскошь (и политическая, и экономическая). Система национальных валют, в которую включилось “евро”, достаточно устойчивое образование, рамки которой сломать не так просто.

"Овеществление Европы" на печатном станке и монетных дворах в полной мере отражает курс на создание Европы всеобщих эквивалентов, переход от дискурсивных практик к бытовым. Таким образом, технология и наука** по-

\footnotetext{
* Заметьте, дискурс - идеологичен.

** В широком смысле, так как имеются в виду и экономические расчеты.
} 
рождают новую политическую реальность; процессы обмена и потребления материальных благ как знаковые для современной цивилизации символически отсылают нас к европейскому единству.

\section{ИДЕНТИЧНОСТЬ}

Описанные выше метафорические системы являются своеобразной средой, в которой конструируется европейская идентичность. Как протекает этот процесс? Прежде чем отвечать на этот вопрос, целесообразно рассмотреть систему идентичности как таковую. Подобно любой другой системе, она может быть устроена либо иерархически, либо как совокупность "автономных атомарных единиц"*. Сопоставим эти два варианта построения идентичности, дабы понять, какой из них более эффективно поддерживал бы институты ЕС.

Иерархическая система обычно многоступенчата, между тем с точки зрения стоящих перед Евросоюзом задач предпочтительнее идентичность "прямая". Никакая “лестница идентичностей", постепенно подводящая к “главной", не сможет дать ему столь мощную легитимацию, как непосредственная (единовременная и однозначная) ассоциация с “европейским”. Культурные и языковые коды, которые отсылают к Европе только при прохождении нескольких ступеней (город, провинция, нация-государство, Западная/Восточная Европа), не в состоянии обеспечить действенную интеграцию на уровне дискурсивных структур. Идентичность первого порядка (в данном случае - “городская") окажется более интенсивной, так как она метафорически роднее человеку, ближе ему.

\section{$\underline{148}$}

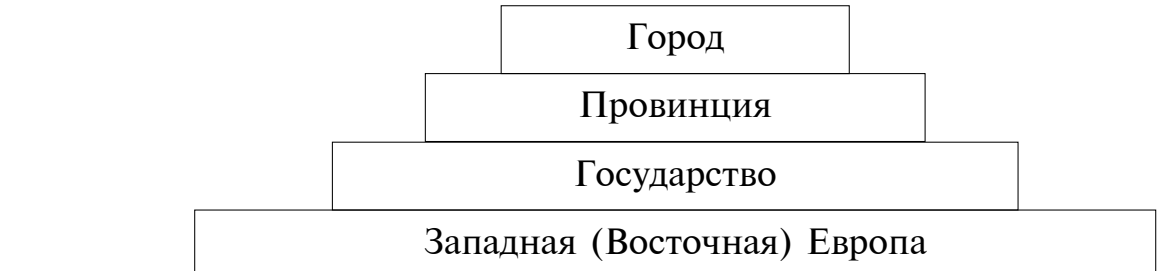

Метафорически передаваемое фундаментальное сходство: “европейскость”

Puc. 1. Пирамида идентичностей (иерархическая метафора)

Изображенная на рис. 1 “иерархия идентичностей” может трактоваться и как пирамида означаемых [Барт 2000]. Другими словами, мы вправе говорить об иерархии смыслов и, следовательно, о присутствии “высшего” (по положению в воображаемом зиккурате идентичностей). Согласно геометрической логике, верхнюю ступень зиккурата занимает самая узкая, т.е. “локальная", идентичность, а собственно "Европа" является лишь его основанием. И хотя метафора "фундамента", возникающая в ходе развертывания геометрической логики, казалось бы хорошо подходит для отражения "европейскости" (благодаря своим позитивным коннотациям), всегда ли “нижняя ступень” проявляется в мышлении европейцев? Более того, если европейская идентичность действительно образует фундамент всех других форм идентичности, то она не нуждается ни в укреплении, ни в поддержке. Развивая метафорику зиккурата, можно заметить, что, как бы парадоксально это ни звучало, политические цели требуют совмещения основания пирамиды с ее вершиной. Множественная идентичность может сработать, но тогда значения “общеевропейский” и “европейский” должны стать не просто основанием - они должны как можно плотнее "схлопнуть" пирамиду смыслов. Эта задача решается в процессе конвенциализации дискурса, метафорическая модель которого была представлена выше.

* Оговорюсь, что в данном случае речь опять идет о метафорах, которые, с одной стороны, помогают называть реальность, но с другой - навязывают понятийные схемы. 
И все же более точно передает суть конструируемой “европейской” идентичности метафора центростремительной системы (“вещей-именований”), в которой отношения не иерархичны, а лишь “завязаны” на центр, на смысловую нагрузку слова “Европа”. Иначе говоря, в качестве знака Европа должна сосуществовать с огромным множеством вещей, но при этом всегда сохранять за собой доминирующее место в системе. Именно соответствующий такой структуре дискурс способен эффективно обслуживать новую политическую общность и цели ее политиков.

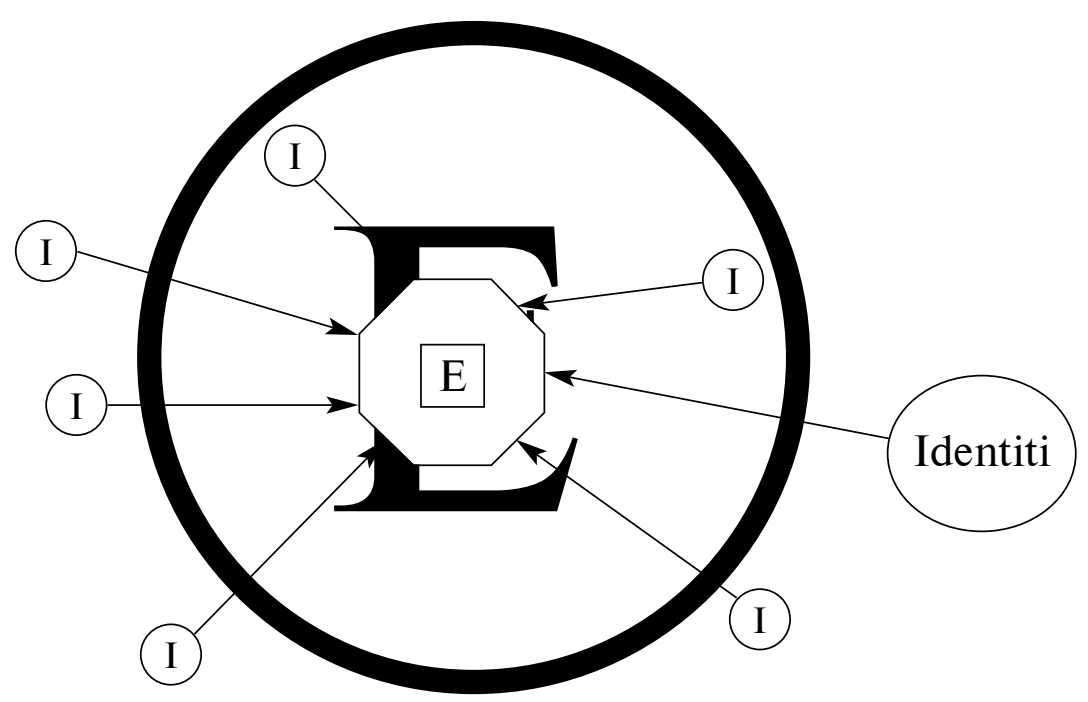

Puc. 2. Альтернативная система идентичностей (сетевая метафора)

Но если так, то формирование европейской идентичности есть одно из проявлений тенденции к вытеснению иерархических структур сетевыми. Как отмечают многие исследователи [см., напр. Кастельс 2000], разнообразные сети играют сегодня главенствующую роль в жизни человека, ибо социализируют гораздо эффективнее традиционных иерархических структур. Таким образом, идентичность видится уже процессом, через который социальные акторы узнают себя и создают смыслы, причем создают их не на основе некой широкой соотнесенности с какими-то социальными структурами, а исходя из совокупности культурных свойств [Кастельс 2000]. Это означает, что идентичность, максимально далекая от иерархических принципов субординации, не только более эффективна, но и попросту неизбежна в современном обществе, главная характеристика которого - стремительное увеличение числа информационных потоков, не контролируемых ни одной конкретной организацией*. Идентичности, возникающие в ходе развития и использования сетей, уже сейчас способны оспорить некоторые из “традиционных” концептуальных идентичностей (например, город/село).

Каждая идентичность отсылает к вполне определенным вещам, пусть и на уровне коннотативных смыслов. Вопрос в том, всегда ли “Европа" является безусловным центром системы таких вещей. Поскольку вещи не могут быть представлены в коммуникации сами по себе, слова их сопровождают и обслуживают - без словесного описания социализация какой бы то ни было вещи едва ли

\footnotetext{
* Весьма показательны в этом плане программы, поддерживающие онлайн-общение через Интернет, например ICQ - свыше 150 млн. зарегистрированных пользователей и 800 млн. сообщений ежедневно (http://company.icq.com/info/community.html). Очевидно, что иерархии заведомо не способны справиться с таким объемом информации.
} 
возможна. Мы стремимся “говорить вещами о вещах, а понятиями о понятиях" [Ильин 1997], отсюда установка на создание различного рода терминологий, которые редуцируют дополнительные смыслы, "расчищают" язык для понимания. В политике же используются обычные слова, но при этом в такие слова вкладывают особые смыслы и обозначают ими вещи особые. (Особые хотя бы потому, что о них говорят политики, избранные на свои посты “волей” граждан.)

“Европа” не относится к числу терминов, а потому это слово, как и любое другое, потенциально способно обозначать феномены (вещи). "Природа" того феномена, который оно выражает, определяется контекстом употребления и ничем иным. Тем не менее, я убежден, что использование концепта "Европа" дискурсивно подразумевает наличие “конкретной” вещи. Пусть эту вещь трудно отделить от понятийной составляющей дискурса, но все же она присутствует. Очевидно, например, что смысловое поле слова “Европа" не ограничивается только именованием топонима. Это слово может применяться по отношению к вещам, не привязанным к географическим координатам, и в процессе такого применения оно становится знаком этих вещей.

Разумеется, меня могут упрекнуть в том, что своими рассуждениями я заранее ставлю Европу в центр системы вещей. В известной степени этот упрек справедлив. Поэтому попытаюсь показать, что предложенный вариант структурирования имеет под собой серьезные основания*. Итак, Европа отсылает к вещи, являющейся главной в системе вещей, к которым, со своей стороны, относятся все идентичности. Почему я веду речь о вещах? Безусловно, в качестве системы идентичностей можно рассматривать тот "мета-язык", на котором о них говорят. К сожалению, это было бы верно лишь в том случае, если бы сфера распространения подобного языка ограничивалась научным сообществом. Поскольку это не так, наш мета-язык, в свою очередь, сам получит социальные (или даже идеологические) коннотации, которые опять замкнут круг на “французскости”, “прусскости”, “корсиканскости” и пр. А “французскость” или “прусскость” может устойчиво существовать только в форме мифа, мифа, которому нужна подпитка в виде разнообразных означающих - peальных вещей или их производных (например, таких категорий, как “исторический факт"). Отсюда следует, что Европу надо анализировать как вещь, тем более, что "в любой вещи принцип реальности всегда может быть вынесен за скобки... проще говоря, за каждой реальной вещью стоит вещь как предмет грезы” [Бодрийяр 1995: 89]. В таком случае Европа есть идеальный образец грезы, и можно привести немало примеров ее системного овеществления.

\section{“ПРИРОДА” ЕВРОПЫ}

Во всех приведенных выше построениях Европа выступала в своей пассивной ипостаси как некое географическое пространство (метафора "Европа есть часть мира"), на котором действовали и действуют субъекты, желающие обладать Европой как простой вещью, присвоить ее себе (метафора "Европа есть вещь”). Однако существует и Европа, сопричастная указанным метафорам, но играющая в их рамках активную, властную роль.

Как уже упоминалось, Европа чем-то сродни идеальной вещи, которая отражает все остальные. Подобная расстановка сил хорошо описывается фразами-клише типа: “в истории Европы было все” (буквально: в Европе есть все). Интересно заметить, что число высказываний по поводу вещи, однажды ставшей предметом интереса, постоянно возрастает. Вместе с тем, как справедливо замечает Бодрийяр, хотя "вещь... способна дать начало социальному дискурсу... это способна сделать не столько наличествующая, сколько отсутствующая вещь” [Бодрийяр 1995: 90]. Именно отсутствием Европы, по-видимому, и объясняются постоянные разговоры о ней. Власть имени “Европа” настолько велика, что по степени приближения к ней (отдаления от нее) в глобаль-

* Вместе с тем сразу же отмечу, что имеющиеся схемы представления столь необычного материала скорее ставят проблемы, чем решают их. 
ных концепциях оцениваются истории целых стран. Так можно ли говорить о Европе как о простом топониме (геониме)? И кроется ли за словом “Европа" какая-либо конкретная вещь-значение, или же его смысл стал действительно всеобъемлющим и всеохватным? Возможно, особое отношение к Европе возникает не только из авторитета именования, но и из нарекаемой одушевляемости, как это происходит со многими знаковыми именами (“дух Америки”, “матушка Россия" и т.д.). То есть дискурсивно Европа может являться вещью одушевленной, вещью, обладающей собственной волей, и тогда объединение Европы предстает даже не просто подчинением этой воле, а долгожданным возвращением к природному (в смысле первоначального и правильного) состоянию. Это тем более так, что человек склонен принимать за реальность тот мир представлений, где одному слову сопоставлена одна вещь*.

Если считать предмет как таковой воплощением пассивности, местом если не совсем мертвым, то, во всяком случае, абсолютно неспособным к какому бы то ни было самовыявлению, то следует, по-видимому, отнестись с недоверием к любым попыткам приоткрыть его внутренние свойства. И здесь мы сталкиваемся с одним из самых важных вопросов, касающихся вещи: а "может ли вещь вообще, или какая-либо вещь в отдельности, обладать определенной внутренней активностью?” [Пепперштейн 1998: 84]. На мой взгляд, такая возможность заложена уже в самом стремлении к овладению вещью, ибо овладеть можно только тем, что оказывает сопротивление, т.е. наделено внутренней активностью (которая делает более значимой победу субъекта или же служит моментом объяснения неудач).

В любом случае представление о полной пассивности Европы разбивается о тексты многих документов Евросоюза. Так, в Лакенской декларации прямо говорится, что объединенная Европа “заняла лидирующую позицию в новом мировом порядке", что она "способна играть стабилизирующую роль в мировом масштабе и указывать пути развития многим странам и народам" [Laeken Declaration 2001]. Если отбросить метафорические модели, то данные утверждения окажутся лишены какой-либо связи с реальностью. Ведь нет никакой объединенной Европы, есть только слабо интегрированный Евросоюз, однако речь упорно идет о том, что он лишь выражает волю европейцев и предназначение Европы.

В настоящее время “битва” за обладание “Европой” сместилась с реальных полей сражений на поля дискурсивные. Мы можем наблюдать процесс кристаллизации “власти имени" в структурах ЕС. Но власть эта настолько сильна и автономна, что в рамках дискурсов “Европа" продолжает играть роль одушевленной вещи. Эта практика тем более эффективна, что, олицетворяя “естественную” власть, Европа привязывает к себе. Никому не уйти от иррациональной власти имен, особенно если эта власть поддерживается современными рациональными институтами.

$$
* * *
$$

При обсуждении проблем функционирования концепта “Европа” мне пришлось проводить, казалось бы, отвлеченные реконструкции. Но именно за ними скрывается уровень идеологии, “псевдоприродности", т.е. социализированная идентичность субъектов. Анализ встроенной в концепт метафорики есть путь к постижению социально-политического смысла концепта.

Итоговый вопрос можно сформулировать следующим образом: Евросоюз ли пытается объединить европейские государства, или же Европа стремится к “естественному” объединению? При втором варианте получается, что объект и субъект объединения един - Европа. Однако из текста работы следует, что смысл слова "Европа" настолько обширен, что конкретные значения легитимны только в специфических дискурсах. Единственный способ их совместить

* Данное утверждение есть скорее онтологическая установка. 
- метафорический, тот, с помощью которого выстраивается наша понятийная система и сглаживается противоречивость перцепции.

Соответственно, в интересах ЕС превратить все существующие дискурсы в политические, дабы каждый из них убеждал в том, что на протяжении всей своей истории Европа была единой вещью естественно, а теперь стремится стать единой актуально. Собственно, такая натурализация метафоры "Европа - вещь” и есть идеология Европейского Союза. Как и любая идеология, она “не признает себя в качестве продукта культуры, обусловленного обществом и его историей; напротив, идеология воспринимает себя как явление 'природы', т.е. как нечто само собой разумеющееся” [Барт 2001: 11].

Сознательной мифологизации может быть подвергнут любой компонент языка, сколь бы многозначным он ни был. Став частью социальной, политической и прочих реальностей, ЕС пытается редуцировать Европу до своей институциональной структуры, дополненной набором стандартных либеральных ценностей (использование метафоры “Европа - это уникальная часть мира", где ярлык уникальности присваивается институтам ЕС). Его борьба с естественным языком неожиданно позволяет ему брать штурмом смысловые поля политики, отождествляя на всех уровнях понимания Европу с Евросоюзом. В результате в дискурсе смешиваются (становятся равнозначными) два мало совместимых представления: (1) Европа в качестве субъекта политики стремится к достижению единства, и (2) Европейский Союз овеществляет (т.е. создает) Европу, приводит ее к реальности.

На уровне научного описания Европа всегда существовала как синтез означаемого и означающего, которые исторически приобретали разные формы (например, Западная Европа в период “холодной войны"). Неожиданно огромный пласт переплетенных значений и знаков оказался означающим для новой Европы с четким означаемым - бережно культивируемым ЕС. Но проблема в том, что означающее настолько сильно, что оставаться только формой оно не может. Дискурс не примет безоговорочно новый знак, не согласится видеть в прошлом лишь выражение сути нынешнего. Поэтому нужны веши нового порядка, которые своей действительностью ежесекундно говорят нам о новом (развертывание метафоры “Европа есть вещь” в метафору “Европа уникальность функциональной вещи"). Ведь до вторжения идеологических коннотаций ЕС концепт “Европа" включал в себя целую совокупность ценностей. Когда же он используется просто как форма для наполнения новыми идеологемами, это разнообразие ценностей устраняется. Похищая значения, мифы завладевают их смыслом и создают симулякры значений, а следовательно - и симулякры вещей. Если означающие большинства выделяемых дискурсов отсылают нас к единому означаемому, мы, скорее всего, имеем дело с вторичной семиологической системой, т.е. с системой мифа [см. Барт 2000]. Иными словами, Европа - это симулякр ЕС.

В заключение стоит отметить, что конечной целью создания конвенциональной европейской идентичности является превращение “Европы” в монолитное пространство полного ценностного консенсуса как воплощения ее извечного стремления стать Евросоюзом. И это так, хотя последний, “идеологически самоустраняясь", предпочитает именовать себя не более чем инструментом, с помощью которого единство “природно-ценностное" может быть преобразовано в единство, оформленное институционально и политически.

Абельсон Р. 1987. Структура убеждений. - Язык моделирования социальных взаимодействий. М.

Барт Р. 2000. Мифологии. М.

Барт P. 2001. S/Z. M.

Бодрийяр Ж. 1995. Система вещей. М.

Вико Дж. 1994. Основания Новой науки об общей природе наций. Киев.

Дейк Т.А. ван. 1989. Язык. Познание. Коммуникация. М.

Европейская интеграция: современное состояние и перспективы. 2001. Минск. 
Ильин М.В. 1997 Слова и смыслы. Опыт описания ключевых политических понятий. М.

Кант И. 1994. Сочинения в восьми томах. Т. 7. М.

Кастельс М. 2000. Информационная эпоха: экономика, общество и культура. М.

Коукер К. 2000. Сумерки Запада. М.

Монне Ж. 2001. Реальность и политика (Мемуары). М.

Обердорфф А. 2001. Политическое становление Европы. - Европейская интеграция: современное состояние и перспективы. Минск.

Олкер Х.Р. 1987. Волшебные сказки, трагедии и способы изложения мировой истории. Язык моделирования социальных взаимодействий. М.

Олкер-мл. Х.Р., Ленерт В.Дж., Шнайдер Д.К. 2001. Иисус Арнольда Тойнби. - Полис, № 6.

Пепперштейн П. 1998. Диета старика. - Пассо и детриумфация. М.

Пеше М. 2002 Прописные истины. Лингвистика, семантика, философия. - Серио П. (ред.) Квадратура смысла: франиузская школа анализа дискурса. М.

Пульчинелли О.Э. 2002. К вопросу о методе и объекте анализа дискурса. - Серио П. (ред.) Квадратура смысла: франиузская школа анализа дискурса. М.

Реале Д., Антисери Д. 1997. Западная философия от истоков до наших дней. СПб.

Руссо Ж.Ж. 1969. Трактаты. М.

Соссюр Ф. де. 1997. Труды по языкознанию. М.

Стросон П.Ф. 1986. Грамматика и философия. - Новое в зарубежнной лингвистике, № 18.

Фихте И.Г. Сочинения. 1995. М.

Фукуяма Ф. 1999. Конеи истории. М.

Фуше М. 1999. Европейская Республика. М.

Хабермас Ю. 2000. Моральное сознание как коммуникативное действие. СПб.

Шенк Р. 1980. Обработка концептуальной информации. М.

Шпенглер О. 1993. Закат Европы. Новосибирск.

Шуман P. 2002.3a Eвpony. М.

Althusser L. 1970. Ideologie et Appareils ideologiques d'Etat. - La Pensŭe, № 151.

Axelrod R. (ed.) 1976. Structure of Decision. Princeton, NJ.

Bonham G.M., Sergeev V.M, Parshin P.B. 1997. The limited Test-Ban Agreement: Emergence of

New Knowledge Structures in International Negotiations. - International Studies Quarterly, vol. 41.

Brubaker R. 1996. Nationalism Reframed: Nationhood and the National Question in the New

Europe. Cambridge.

Butler N. 2003. A Clean Break for Europe. - CER Bulletin, № 32

(http://www.cer.org.uk/articles/32_butler.html)

Dijk T.A. van. 1982. Opinions and Attitudes in Discourse Comprehension. - Language and Comprehension. Amsterdam.

Doorstep interview by the Prime Minister in Brussels. (2003)

(http://www.number-10.gov.uk/output/Page5029.asp).

Gordon Ph.H. 2003. Bridging the Atlantic Divide. - Foreign Affairs, vol. 2, № 1.

European Summit Ends in Failure. 2003. (http://news.bbc.co.uk/2/hi/europe/3315447.stm).

Laeken Declaration - The Future of the European Union. 2001.

Lakoff G. 1987. Women, Fire, and Other Dangerous Things: What Categories Reveal About the Mind. Chicago.

Lakoff G. 1992. The Contemporary Theory of Metaphor

(http://www.ac.wwu.edu/ market/semiotic/lkof_met.htm).

Lakoff G., Johnson M. 1980. Metaphors We Live By. Chicago.

Lehnert W.G. 1981. Plot Units and Narrative Summarizations. - Cognitive Science, vol. 4.

Pкsheux M. 1969. Analyse automatique du discours. P.

PM Statement on the European Council 12-13 December. (2002)

(http://www.number-10.gov.uk/output/Page1745.asp ).

The Prime Minister's interview with Sky News in Dublin on Saturday 1st May 2004. (2004)

(http://www.number-10.gov.uk/output/Page5753.asp).

Ricoeur P. 1981. Hermeneutics and the Human Sciences. Cambridge.

Wendt A. 1999. Social Theory of International Politics. Cambridge.

Wallerstein I. 1974. The Modern World System: Capitalist Agriculture and the Origins of the European World Economy in the Sixteenth Century. N.Y. 